\title{
GENERAL THEORETICAL CHARACTERISTICS OF GENDER-BASED VIOLENCE
}

The article is devoted to the study of gender-based violence. In the process of integration into the European Union, Ukraine reaffirmed its desire to build a European country dominated by democratic principles. The theoretical and legal aspects of genderbased violence in Ukraine in general and in its eastern part in particular were revealed. It is substantiated that the achievement of this goal actualizes the issue of gender equality. The spread of violence in society is caused by the deterioration of the social and economic situation of many Ukrainian families against the backdrop of hostilities and the economic crisis. It is noted that the influence of Soviet totalitarianism is one of the main factors in committing gender-based violence. On the basis of the scientific points of view on understanding the definition of the concept of gender-based violence, the author's definition is proposed. Considering the types of gender-based violence, one more thing which stands out is inaction. Attention is paid to the fact that the problem of legal regulation of genderbased violence is of paramount importance. It is observed that the urgent issue is to bring the current legislation in line with the Laws of Ukraine "On Equal Rights and Opportunities for Women and Men" and "On Prevention and Countering Domestic Violence". The mechanism of counteracting gender-based violence in foreign countries was analysed. The mechanism of counteracting gender-based violence was defined as a set of interrelated elements that form its structure and are functionally aimed at achieving the main goal of overcoming various forms of violence, detecting and terminating its manifestations in all spheres of human activity, restoring the legal rights and interests of those who have suffered violence, elimination of the consequences of the latter.

Key words: human rights, gender, gender policy, gender equality principle, gender discrimination, equality between men and women, violence, gender-based violence, gender mainstreaming mechanism, European Court of Human Rights.

Статтю присвячено дослідженню гендерно зумовленого насильства. Україна у процесі інтеграції до Європейського Союзу підтвердила своє бажання побудувати європейську країну, у якій пануватимуть демократичні принципи. Обгрунтовано, що досягнення зазначеної мети актуалізує питання щодо забезпечення гендерної рівності. Розкрито теоретико-правові аспекти гендерно зумовленого насильства в Україні загалом та в іiї східній частині зокрема. Вчинення насильства за ознакою статі в суспільстві віддзеркалює систему владних відносин, де відсутній демократичний принцип розбудови суспільства. Поширення насильства в ньому зумовлене погіршенням соціальної й економічної ситуації багатьох українських сімей на тлі воєнних дій та економічної кризи. Зазначено, що серед головних чинників вчинення гедерно зумовленого насильства можна назвати вплив радянського тоталітаризму. На основі викладених наукових позицій щодо розуміння поняття гендерно зумовленого насильства запропоновано авторську дефініцію. 3 огляду на види гендерно зумовленого насильства виокремлено ще один - бездіяльність. Акцентовано увагу на тому, що першочергового розгляду потребує проблема правового регулювання гендерно зумовленого насильства. Зауважено, що нагальним питанням $є$ узгодження чинного законодавства із законами України «Про забезпечення рівних прав та можливостей жінок і чоловіків» та «Про запобігання та протидію домашньому насильству». Проаналізовано механізм протидії гендерно зумовленому насильству в зарубіжних країнах, який визначено як сукупність взаємопов'язаних елементів,

(C) NALYVAIKO L.R. - Doctor of Law Sciences, Professor, Honored Lawyer of Ukraine, Vice-Rector (Dnipropetrovsk State University of Internal Affairs)

(C) LAVRENKO D.O. - Master's Student of the Faculty of Law (Dnipropetrovsk State University of Internal Affairs) 
які утворюють його структуру та функціонально спрямовані на досягнення основної мети - подолання різних форм насильства, виявлення й припинення його проявів у всіх сферах життєдіяльності людини, поновлення законних прав та інтересів осіб, які зазнали насильства, усунення його наслідків.

Ключові слова: права людини, гендер, гендерна політика, принцип гендерної рівності, дискримінація за статевою ознакою, рівність прав чоловіків $і$ жінок, насильство, гендерно зумовлене насильство, механізм забезпечення принципу гендерної рівності, Європейський суд з прав людини.

Introduction. Gender-based violence is inherent in every country and in all segments of the population. In the process of integration into the European Union, Ukraine has confirmed its desire to build a European country in which democratic principles will dominate and human rights will be the highest priority. Achieving this goal highlights the issue of gender equality, in particular the eradication of gender-based violence in society. Neglecting gender-based violence will undermine the principles of a democratic society.

Setting objectives. The theoretical foundations of gender-based violence in Ukraine have been explored in the works by such domestic and foreign scholars as N. Anishchuk, N. Bolotina, I. Grytsai, G. Gerasymenko, O. Dashkovska, L. Kobelianska, K. Levchenko, T. Martseniuk, T. Melnyk, V. Muranov, M. Nychyporenko, O. Rudnieva, G. Hristova, L. Yerokhina, Y. Cherniak, and others. However, it is important to formulate a definition on the basis of a thorough analysis of gender-based violence.

Research results. In today's Ukrainian society, gender-based violence is destroying the strategy of building a European state. In particular, open neglect of the problem of gender-based violence in society leads to the elimination of others, including the basic principles of a democratic society. The spread of violence in society is caused by the deterioration of the social and economic situation of many Ukrainian families against the backdrop of hostilities and the economic crisis.

Gender-based violence is a structural problem that is deeply rooted in the unequal balance of power between men and women. Such violence is exacerbated by the harmful social and cultural expectations and perceptions of gender roles that are commonly considered to be inherent in a woman or man, girl or boy. Thus, gender inequality is embodied and maintained in practice. Women and girls who are subject to violence receive a signal that they are not good enough and do not control their life and body. This has a direct impact on women's health, employment and participation in public and political life [1].

The definition of gender-based violence and the definition of the author's definition are paramount. For the first time, the definition of gender-based violence in Ukrainian legislation was enshrined in the Law of Ukraine "On Equal Rights and Opportunities for Women and Men". These are sexual assault, or common practices or traditions in society (stereotyped perceptions of the social functions (status, responsibilities, etc.) of women and men), or acts concerning mainly persons of a particular gender or affecting disproportionately causing physical, sexual, psychological or economic harm or suffering, including the threat of such acts, in public or private life [2]. It should be emphasised that this law has been in force since 2005, but the legislative recognition of the investigated definition was introduced only in 2017 (with the adoption of the Law of Ukraine "On Prevention and Countering Domestic Violence").

There are three main approaches to determining (interpreting) what constitutes gender-based violence [3], namely: the first approach is based on the definition enshrined in the Declaration on the Elimination of Violence against Women, according to which violence against women means any act of sexual violence that causes or may cause physical, sexual or psychological harm or suffering to women, as well as threats of such acts, coercion or arbitrary imprisonment, whether in the public domain or personal life [4]. The second approach is reflected in the theory of masculinity and involves violence against women, some men, and sexual abuse of children. Homophobic violence, sexual abuse and child abuse are covered by this theory. This theory is supported by J. Lang, who sees that in order to achieve the goal of homophobia and human trafficking, a certain hierarchy is used for sexual slavery, where privileges are still enjoyed by men [5]. The third approach is based on gender-based violence and the social role of the man or woman.

The Population Services International (PSI) defines gender-based violence as violence directed at a person based on their biological sex, gender identity [6]. Under gender-based violence the Office of the UN High Commissioner for Refugees understands any act committed against the will of a person and based on gender norms and unequal power relations [7]. 
In the scientific literature, scholars have interpreted gender-based violence differently, but all have said that it is gender-based violence. By gender-based violence V. Popil, in particular, understands the socially dangerous behaviour of a person (abuser), both male and female, regarding the opposite sex (victim), which manifests itself in causing physical, sexual, moral-psychological and other suffering or in threats of their use [8]. S. Yevchenko interprets gender-based violence as a violation of human rights violence formed on the use of gender-based power (including verbal abuse, threats, beatings, coercion, etc.) [9]. L. Goniukova believes that gender violence is a kind of aggressive behaviour, the use of force on the basis of gender - from verbal abuse and threats to physical beatings and coercion [10]. A. Maksimov emphasises that gender-based violence is the result of gender discrimination and is embodied in various forms, each of which violates human rights but also destabilizes society, contributing to its degradation and destructuring [11]. Foreign scientists J. Benjamin and L. Marchison interpret gender-based violence as violence used against women, girls, men and boys to affirm and reproduce gender roles and norms. According to this understanding, gender-based violence can occur equally to a person of any gender and is used to enhance gender roles. This includes violence against women and girls, sexual abuse of men and violence against girls as they are girls and boys as they are boys, for example, the recruitment of boys into armed groups [12]. Thus, these are actions (inactions) of a person (group of persons) against another person (group of persons), which are aimed at the deterioration of the gender in all spheres of vital status of a man/woman and lead to the violation of human rights, thus undermining the health, dignity, as well as security, economic and social stability of the nation.

As a result of the imbalance in maintaining gender parity in society, most cases of violence are perpetrated by men against women. It is important to maintain a gender perspective in the relationship between men and women.

When researching the content of gender-based violence, the question becomes relevant as to its causes and forms of manifestation. M. Kaczynska divides gender-based violence into "public" (general) and "private" (family). The first type of gender-based violence is perpetrated against a person in public life, that is, at work, training, or in society at large, such as a ban on voting based on a person's gender. The second type of gender-based violence, namely domestic violence, is a private, domestic affair. Today, the law provides for legal liability for committing an act of violence [13].

Domestic scientists L. Kobylianska and T. Melnyk identify the following main manifestations of gender-based violence: physical, sexual, psychological, and economic violence that shows up in family relationships; physical, sexual, psychological, and economic violence that takes place in society; physical, sexual, psychological, economic violence that occurs on the part of the state or when the state neglects its obligations; violence related to the violation of women's rights in conflict zones; the threat of violence for groups such as women of national minorities, refugees, migrants, elderly women, repatriate women, etc. [14].

To the types of gender-based violence T. Martseniuk proposes to include: physical, psychological, economic and sexual violence, trafficking in women, sexual harassment, child (early) marriages [15]. According to the European Information and Research Centre the main manifestations of violence are: rape, sexual harassment at work, prompting abortion; compulsion for the birth of a child, extreme jealousy, a ban on communication with other men; a ban on work; trafficking in women, domestic violence, including physical, psychological, sexual and economic violence [16]. Taking into account the types of gender-based violence that can be distinguished in the scientific literature, namely inaction, which is understood to mean that a person of one sex witnesses the perpetration of any violence against a person of the opposite sex, and instead of taking actions aimed at protecting the latter, exploits an opportunity for their own needs or interests.

In the context of establishing Ukraine as a European country, the issue of legal regulation of gender-based violence in Ukraine is of paramount importance. The legislator's attitude to gender-based violence has changed somewhat over the last few years. The Verkhovna Rada of Ukraine together with the Cabinet of Ministers of Ukraine are actively adopting normative legal acts aimed at solving the problem under study. However, in our opinion, there is still a long way to go to effectively address the phenomenon of gender-based violence in society.

The legal regulation of the prevention and counteraction of gender-based violence in Ukraine begins with the Constitution of Ukraine. According to article 3 of the Basic Law of Ukraine, a person, his life and health, honour and dignity, integrity and security are recognized in Ukraine as the highest social value [17]. The Law of Ukraine "On Prevention and Countering Domestic Violence" defines the organizational and legal principles of prevention and counteraction to domestic violence, the main directions of implementation of the state policy in the field of prevention and counteraction to domestic 
violence, aimed at protecting the rights and interests of the victims of such violence [18]. It is a law aimed at regulating relationships that arise during the commission of a particular form of gender-based violence, that is domestic violence, and which is subject to an exhaustive list of persons.

The Law of Ukraine "On Combating Trafficking in Human Beings" establishes the organizational and legal foundations of combating trafficking in human beings, guaranteeing gender equality, the main directions of state policy and principles of international cooperation in this field, the procedure for establishing the status of victims of trafficking and assistance to persons [19]. The problem of human trafficking and its eradication in our society has a long process.

The Law of Ukraine "On Social Work with Families, Children and Youth" regulates the provision of assistance and implementation of socially preventative work with persons who have been subjected to gender-based violence, and provides for comprehensive measures aimed at preventing family disadvantage, social orphanage, domestic violence and ill-treatment of children, trafficking in human beings, the worst forms of child labour, social-therapeutic and psychological rehabilitation in relevant child and youth health institutions for those who have experienced abuse and, in particular, domestic violence [20]. The concept of the State Social Programme for Ensuring Equal Rights and Opportunities for Women and Men for the Period up to 2021 provides that the main causes of gender inequality in Ukrainian society include the lack of a comprehensive system of response to gender discrimination, prevention of gender-based violence and discrimination and assistance to victims of violence" [21].

The Cabinet of Ministers of Ukraine Decree of December 13, 2017 "On Approval of the State Targeted Programme for Recovery and Peacebuilding in the Eastern Regions of Ukraine" defines tasks and measures for peacebuilding, including enhancing security in territorial communities and implementing measures to prevent gender-based violence [22]. The Resolution came into force in January 2018 after the amendments to the Law of Ukraine "On Equal Rights and Opportunities for Women and Men" were introduced.

In the Order of the Cabinet of Ministers of Ukraine dated September 5, 2018 "On approval of the National Action Plan on the implementation of the recommendations set out in the concluding observations of the UN Committee on the Elimination of Discrimination against Women to the Eighth Periodic Report of Ukraine on the Implementation of the Convention on the Elimination of All Forms of Discrimination against Women by 2021" it was recommended to take priority measures to effectively combat corruption and impunity and to fulfill the previously undertaken commitment to prevent, investigate, re-pursue the leadership and punishment of violence against women and girls by state and non-state actors" [23]. In several orders some forms of gender-based violence are identified.

The concept of the National Social Agenda for Preventing and Combating Domestic and Gender-Based Violence for the Period up to 2023 enshrines that domestic and gender-based violence are manifestations of human rights violations and major obstacles to gender equality. The purpose of the said programme is to ensure the development of a system for preventing and combating domestic and gender-based violence in accordance with international standards and the Law of Ukraine "On Prevention and Countering Domestic Violence" in the context of decentralization and implementation of comprehensive measures and actions aimed at reducing the scale of such phenomenon [24]. The above order is the only one in the context of the correspondence of the meaning of the term gender-based violence to the current legislation.

The order of the Ministry of Social Policy of Ukraine from September 17, 2012 "On approval of the recommendations for holding the annual action 16 Days Against Violence" states that one of the main tasks of holding such an action in the regions of Ukraine (from November 25 to December 10) is attracting the public's attention to the issues of concern for Ukrainian society in combating domestic violence, countering trafficking in human beings and child abuse, gender-based violence, and ensuring equal rights for women and men and for local or regional national events, public hearings on the prevention of domestic violence, gender-based violence and trafficking in human beings [25].

In order to ensure effective cooperation between Ukraine and other countries, in December 2017, a memorandum of understanding was signed with the Ministry of Education of the Portuguese Republic on cooperation in the youth, physical culture and sports fields, including promoting gender equality and counteracting gender equality [26].

The Ministry of Education and Science of Ukraine has developed and approved methodological recommendations on prevention and counteraction to violence in order to fulfill the legislative requirements of the Law of Ukraine "On Prevention and Countering Domestic Violence", which outlines the algorithm of actions for detecting domestic violence and substantiates the need for formation of children and young people violent behaviours, indifferent treatment of victims, and awareness of 
violence as a violation of human rights addressed to all professionals, as working with children and young people [27].

For the first time, the term "gender-based violence" was enshrined at the legislative level, but the legal acts which were in force before the Law of Ukraine "On Prevention and Countering Domestic Violence" came into force did not comply with the requirements of paragraph 4 of the final provisions of this law.

In an effort to overcome gender-based violence in order to create a society in which democracy existed, human rights and freedoms were defended, our country ratified international normative acts, among which we should pay attention to: the Universal Declaration of Human Rights of 1948; the Declaration on the Elimination of Violence against Women, proclaimed by the UN General Assembly Resolution of 1993; the 1949 Convention to Combat Trafficking in Persons and the Exploitation of Prostitution by Third Parties; the 1979 UN Convention on the Elimination of All Forms of Discrimination against Women; Optional Protocol to the 1999 Convention on the Elimination of All Forms of Discrimination against Women; the 1987 Convention against Torture and Other Cruel, Inhuman or Degrading Treatment or Punishment; the Declaration of the Committee of Ministers of the Council of Europe on equality between women and men of 1988; United Nations Convention on the Rights of the Child 1989; the 1999 Convention on the Prohibition and Immediate Measures to Eliminate the Worst Forms of Child Labour; International Covenant on Civil and Political Rights of 1973 and the like.

In the context of exacerbating gender-based violence in order to effectively address issues in the field of research, it is necessary to amend the international and national legislation annually.

The urgent issue is to bring the current legislation into line with the Laws of Ukraine "On Equal Rights and Opportunities for Women and Men" and "On the Prevention and Counteraction of Domestic Violence", since the use of terminology different from the content of the relevant law is inadmissible.

Conclusions. On the basis of the stated scientific points of view on understanding the definition of gender-based violence, we consider that these are actions (inaction) of a person (group of persons) against another person (group of persons), which are aimed due to the deterioration in the society in all spheres of life status of a man/woman at performing gender roles and violate human rights, undermining the health, dignity and security, economic, and social stability of the nation. Considering the types of gender-based violence reported in the scientific literature, we can distinguish one more type, namely, inaction, that is, the person of one gender witnessing the perpetration of any violence against a person of the opposite sex, and instead of protecting the latter, using this opportunity for their own interests. One of the main factors in the perpetration of gender-based violence in Ukrainian society is the influence of Soviet totalitarianism. It was then that the patriarchal order was defined, which destroyed gender parity and determined the place of women in modern society. It is necessary to amend the Law of Ukraine "On Equal Rights and Opportunities for Women and Men" article 11 with the following content: forms of gender-based violence are: physical, sexual, psychological, economic, domestic, trafficking, early childhood marriages, rape, prompting abortion, coercion, inaction, etc. In the absence of legal forms/ types of violence, in particular, it is impossible to develop a strategy to effectively combat gender-based violence.

\section{References:}

1. Kelly L. How violence is constitutive of women's inequality and the implications for equalities work. London : Metropolitan University, 2005. 25 p.

2. Про забезпечення рівних прав та можливостей жінок і чоловіків : Закон України від 8 вересня 2005 р. № 2866-IV / Верховна Рада України. Відомості Верховної Ради України. 2005. № 52. Ст. 561.

3. Hamilton S. Gender-based violence: a confused and contested term. URL: https://odihpn.org/ magazine/gender-based-violence-a-confused-and-contested-term.

4. Декларація про викорінювання насилля щодо жінок : міжнародний документ від 20 грудня 1993 р. № 995_506 / OOH. URL: http://zakon.rada.gov.ua/laws/show/995_506.

5. Lang J. Men, Masculinities and Violence. International Conference "Erā̄icating Violence against Women and Girls - Strengthening Human Rights", Berlin, 2-4 December 2002. URL: http://menengage.org/wp-content/uploads/2014/06/Men_Masculinities_and_Violence.pdf.

6. Gender-based Violence. URL: https://www.psi-org/health-areä/gender-based-violence/\#about.

7. Elimination of Violence Against Women. Commission on Human Rights Resolution 2004/46. Geneva : Office of the high commissioner for human rights, 2004. 8 p. 
8. Попіль В. Гендерне насильство: кримінально-правові та кримінологічні аспекти. URL: http://vuzlib.com/content/view/127/60/.

9. Євченко С. Гендерне насильство (gender violence). Енциклопедія прав людини: соціальнопедагогічний аспект : монографія / за заг. ред. Н. Сейко. Житомир, 2014. С. 145-149.

10. Гонюкова Л. Гендерна політика в Україні: проблеми та перспективи. Гендерна політика міст: історія і сучасність : матеріали II Міжнар. наук.-практ. конф., м. Харків, 23-25 жовтня 2013 р. Харків, 2013. Вип. 2. С. 33-38.

11. Максимов А. Теоретические проблемы определения и соотношения гендерного насилия и гендерной дискриминации. Исторические, философские, политические и юридические науки, культурология и искусствоведение. Вопросы теории и практики. 2012. № 10(24). Ч. 1. С. 119-121.

12. Benjamin J., Murchison L. Gender-Based Violence: Care and Protection of Children in Emergencies - A Field Guide. URL: https://resourcecentre.savethechildren.net/sites/default/files/ documents/1385.pdf.

13. Качинська М. Гендерно-обумовлене насильство. Право і суспільство. 2017. № 2. С. 14-17. 2005. $280 \mathrm{c}$.

14. Мельник Т., Кобелянська Л. 50/50 Сучасне гендерне мислення : словник. Київ : К.І.С.,

15. Марценюк T. Годі терпіти: усе про гендерне насильство проти жінок. URL: https:// genderindetail.org.ua/season-topic/genderne-nasilstvo/godi-terpiti-use-progenderne-nasilstvo-protizhinok-134410.html.

16. Савчук О. Аспекти протидії гендерному насильству - практика в Україні: інформаційна довідка, підготовлена Європейським інформаційно-дослідницьким центром на запит Комітету Верховної Ради України. URL: http://radaprogram.org/sites/default/files/infocenter/piblications/ aspekty protydiyi_gendernomu_nasylstvu.pdf.

17. Конституція України : Закон України від 28 червня 1996 р. № 254/96-ВР / Верховна Рада України. Відомості Верховної Ради України. 1996. № 30. Ст. 141.

18. Про запобігання та протидію домашньому насильству : Закон України від 2 лютого 2018 p. № 2229-VIII / Верховна Рада України. Відомості Верховної Ради України. 2018. № 5. Ст. 35.

19. Про протидію торгівлі людьми : Закон України від 20 вересня 2011 р. № 3739-VI / Bepховна Рада України. Відомості Верховної Ради України. 2012. № 19-20. Ст. 173.

20. Про соціальну роботу з сім’ями, дітьми та молоддю : Закон України від 21 червня 2001 р. № 2558-III / Верховна Рада України. Відомості Верховної Ради України. 2001. № 42. Ст. 213.

21. Про затвердження Державної соціальної програми забезпечення рівних прав та можливостей жінок і чоловіків на період до 2021 року : Постанова Кабінету Міністрів України від 11 квітня 2018 р. № 273-2018-п / Кабінет Міністрів України. Офіиійний вісник України. 2018. № 33. Ст. 1165.

22. Про затвердження Державної цільової програми відновлення та розбудови миру в східних регіонах України : Постанова Кабінету Міністрів України від 13 грудня 2017 р. № 1071 / Кабінет Міністрів України. Офіційний вісник Украйни. 2018. № 6. Ст. 248.

23. Про затвердження Національного плану дій з виконання рекомендацій, викладених у заключних зауваженнях Комітету ООН з ліквідації дискримінації щодо жінок до восьмої періодичної доповіді України про виконання Конвенції про ліквідацію всіх форм дискримінації щодо жінок на період до 2021 року : Розпорядження Кабінету Міністрів України від 5 вересня 2018 p. № 634-p / Кабінет Міністрів України. URL: https://www.kmu.gov.ua/ua/npas/pro-go-planu-dijz-vikonannya-rekomo-zhinok-dovosmoyi-periodichnoyi-dopovidi-ukrayini-pro-vikonannyakonvenciyi-pro-likvidaciyuvsih-form-diskriminaciyi-shchodo-zhinok-na-period-do-2021-roku.

24. Про схвалення Концепції Державної соціальної програми запобігання та протидії домашньому насильству та насильству за ознакою статі на період до 2023 року : Розпорядження Кабінету Міністрів України від 10 жовтня 2018 р. № 728-р / Кабінет Міністрів України. Офіиійний вісник України. 2018. № 82. Ст. 2726.

25. Про затвердження рекомендацій щодо проведення щорічної акції «16 днів проти насильства» : Наказ Міністерства соціальної політики України від 17 вересня 2012 р. № 581 / Міністерство соціальної політики України. URL: http://zakon.rada.gov.ua/rada/show/v0581739-12.

26. Меморандум про взаєморозуміння між Міністерством молоді та спорту України і Міністерством освіти Португальської Республіки щодо співробітництва у молодіжній сфері, сфері фізичної культури і спорту : міжнародний документ від 18 грудня 2017 р. / Міністерство молоді та спорту України, Португальська Республіка. Офіиійний вісник Украӥни. 2018. № 15. Ст. 544.

27. Методичні рекомендації щодо запобігання та протидії насильству : лист Міністерства освіти і науки України від 18 травня 2018 р. № 1/11-5480 / Міністерство освіти і науки України. URL: https://drive.google.com/file/d/1GU-yUiXyeQr3z6X0MWd7mf2AFVaeGFF5/view. 